\title{
2
}

\section{Issues Facing the Birth Parents and Their Implications for Open Adoption}

\section{Introduction}

The most complex and difficult decisions that child welfare professionals have to make are those concerning the safety of children. Decisions about whether parents have sufficient capacity to change circumstances and behaviour patterns that pose a risk of significant harm to their child, or whether the problems they face are so severe that the child can only be adequately protected through removal, are often finely balanced. On the one hand, leaving a child in an abusive environment can have serious and sometimes life-changing consequences, yet on the other hand, unnecessary or premature removal not only contravenes ethical standards and human rights legislation, it too may also have long-term adverse consequences for both parent and child (Broadhurst et al., 2016; Brown \& Ward, 2014; Brown et al., 2016; Neil et al., 2010). This chapter focuses on the adoptees' birth parents; it explores the complex problems with which they struggled. Many of these were known risk factors, such as substance misuse, mental health problems and domestic abuse, that reduce parents' capacity to provide nurturing homes for their children and jeopardise their long-term wellbeing. Professionals had to assess these and other factors in deciding whether or not the adoptees could safely 
remain living with their birth parents, or whether they needed to be placed in out-of-home care on a temporary or permanent basis.

Between 1 July 1987 and 30 June 2013, the courts made adoption orders for 210 children placed through the Barnardos Find-a-Family programme. The children had entered their adoptive homes between 12 February 1979 and 7 July 2011. The documents and reports held on the Barnardos files and electronic information system provide a wealth of information concerning the children's experiences, both while living with birth parents before being separated and then during the period between separation and final placement with the adoptive family. Nearly one in five $(19 \%)$ of the children had had their fifth birthday before they left their birth parents' home, and nearly one in four (24\%) were six years old or more before they entered their adoptive homes, so many of them could remember the time before they were adopted. The interviews with adult adoptees illuminate much of the information held on files.

It is worth exploring these data in some detail because they shed light on the extreme vulnerability of not only the adoptees, but also their birth parents at the time key decisions were made, thus clarifying the reasons why the children were first placed in out-of-home care and then referred to the Find-a-Family programme with a view to adoption.

They also point to the challenges Barnardos faced in introducing and maintaining a programme of open adoption, and the difficulties some adoptive parents were likely to have encountered in trying to meet the children's needs.

\section{Birth Parents}

Most (58\%) of the 210 children in the full cohort entered Find-a-Family with at least one sibling; altogether they came from 142 birth families. Before entry to out-of-home care, almost all the children (205: 98\%) had been primarily looked after by their birth mothers; only three children had had their father as their primary carer and two had been looked after by adoptive mothers, in placements made by other agencies that had disrupted before referral to the programme. Nothing is known about the birth families of these two children and the following paragraphs focus on the 140 families for whom data are available. 
The majority of the birth mothers were Australian or New Zealanders (111: 79\%) or European (21: 16\%). Adoption is not considered appropriate for Aboriginal children (see Chap. 1) and none of the mothers were Aboriginal, although four were Maori or Pacific Islanders. The fathers were slightly more diverse: 83 (72\%) were Australian or New Zealanders and $18(16 \%)$ were European; however, four fathers were Asian, five were Maori or Pacific Islanders and three were found to be Aboriginal after the children's placement.

There is comprehensive information about all the 137 birth mothers who acted as primary carers and $120(85 \%)$ of the fathers. Only 17 fathers were unknown.

\section{Birth Parents' Relationships}

Tables 2.1 and 2.2 show the birth parents' relationship status at the time the children were born compared with when they were placed for adoption. Almost three-quarters (98: 70\%) of birth mothers were still in a relationship with the children's birth fathers at the time the children were born; only $31(22 \%)$ of them were lone parents. However, by the time of the adoption, on average nine years later, $90 \%$ of the parents had split up. Only $14(10 \%)$ of the mothers were still in a relationship with the birth father, about one in three (45:32\%) had moved on to a new partner, and another third (43:31\%) were now lone parents. Thirty (21\%) of the fathers had also moved on to a new partner. Although as a group the parents were relatively young, a high proportion (16 (11\%) of birth mothers and 11 (8\%) of birth fathers) had already died. There was no information available concerning almost half (59: 42\%) the birth fathers at the time their children entered their adoption placements, possibly because they had already lost touch.

Frequent changes in parental relationships are a common experience of children who are placed in out-of-home care (Wade et al., 2011; Ward et al., 2006) and are one of the reasons why maintaining contact was likely to be problematic for this cohort of children. The high proportion of parents who had changed partners may also reflect some of the risk factors that diminished their capacity to parent (discussed below) and which may well have also had an adverse impact on their capacity to form stable relationships. 
Table 2.1 Birth mothers: relationship status at child's birth and at adoption $(N=140)$

\begin{tabular}{|c|c|c|c|c|}
\hline & \multicolumn{4}{|c|}{ Birth mother's relationship status at birth } \\
\hline $\begin{array}{l}\text { Birth mother's } \\
\text { relationship status at } \\
\text { adoption }\end{array}$ & $\begin{array}{l}\text { Both parents } \\
\text { together in a } \\
\text { relationship }\end{array}$ & $\begin{array}{c}\text { In a } \\
\text { relationship } \\
\text { with a different } \\
\text { partner }\end{array}$ & Single & Total \\
\hline $\begin{array}{l}\text { Birth parents together } \\
\text { in a relationship }\end{array}$ & 14 & 0 & 0 & $\begin{array}{r}14 \\
(10 \%)\end{array}$ \\
\hline $\begin{array}{l}\text { In a relationship with a } \\
\text { different partner }\end{array}$ & 27 & 5 & 13 & $\begin{array}{r}45 \\
(32 \%)\end{array}$ \\
\hline Single & 27 & 3 & 13 & $\begin{array}{r}43 \\
(31 \%)\end{array}$ \\
\hline Deceased & 15 & 1 & 0 & $\begin{array}{r}16 \\
(11 \%)\end{array}$ \\
\hline $\begin{array}{l}\text { Relationship status } \\
\text { unknown }\end{array}$ & 15 & 2 & 5 & $\begin{array}{r}22 \\
(16 \%)\end{array}$ \\
\hline Total & $98(70 \%)$ & $11(8 \%)$ & $31(22 \%)$ & 140 \\
\hline
\end{tabular}

Table 2.2 Birth fathers: relationship status at child's birth and at adoption $(N=140)$

\begin{tabular}{|c|c|c|c|c|c|c|}
\hline & \multicolumn{6}{|c|}{ Birth father's relationship status at birth } \\
\hline $\begin{array}{l}\text { Birth } \\
\text { father's } \\
\text { relationship } \\
\text { status at } \\
\text { adoption }\end{array}$ & $\begin{array}{c}\text { Both } \\
\text { parents } \\
\text { together in a } \\
\text { relationship }\end{array}$ & $\begin{array}{c}\text { In a } \\
\text { relationship } \\
\text { with a } \\
\text { different } \\
\text { partner }\end{array}$ & Single & $\begin{array}{c}\text { Relationship } \\
\text { status } \\
\text { unknown }\end{array}$ & $\begin{array}{l}\text { Missing/ } \\
\text { father } \\
\text { unknown }\end{array}$ & Total \\
\hline $\begin{array}{l}\text { Birth parents } \\
\text { together in a } \\
\text { relationship }\end{array}$ & 14 & 0 & 0 & 0 & & $\begin{array}{r}14 \\
(10 \%)\end{array}$ \\
\hline $\begin{array}{l}\text { In a } \\
\text { relationship } \\
\text { with a } \\
\text { different } \\
\text { partner }\end{array}$ & 24 & 0 & 1 & 5 & & $\begin{array}{r}30 \\
(21 \%)\end{array}$ \\
\hline Single & 20 & 0 & 4 & 2 & & $\begin{array}{r}26 \\
(19 \%) \\
\end{array}$ \\
\hline Deceased & 10 & 0 & 0 & 1 & & $\begin{array}{r}11 \\
(8 \%) \\
\end{array}$ \\
\hline $\begin{array}{l}\text { Relationship } \\
\text { status } \\
\text { unknown }\end{array}$ & 30 & 3 & 5 & 4 & & $\begin{array}{r}42 \\
(30 \%)\end{array}$ \\
\hline $\begin{array}{l}\text { Missing } \\
\text { (father } \\
\text { unknown) }\end{array}$ & & & & & 17 & $\begin{array}{r}17 \\
(12 \%)\end{array}$ \\
\hline Total & $98(70 \%)$ & $3(2 \%)$ & $10(7 \%)$ & $12(9 \%)$ & $17(12 \%)$ & 140 \\
\hline
\end{tabular}




\section{Factors That Affected Parenting Capacity}

There is now a well-established body of evidence that shows how a range of adverse factors can impact on parents' capacity to meet their children's needs (for overview, see Cleaver et al., 2011). Poverty, poor housing, a hostile environment and social isolation are all known to increase the challenge of parenting and make abuse and neglect more likely, although these are neither sufficient nor necessary factors in the occurrence of child maltreatment (Bywaters et al., 2016). Although we know that the vast majority of the birth parents faced these adversities, as is common to most child welfare agencies (see Bywaters, 2013), data were not routinely collected on these issues.

There is a known relationship between parenting capacity and parents' age, with very young parents being more likely to show abusive or neglectful parenting. Forty-two (20\%) children were born to a birth mother who was younger than $20 ; 170(81 \%)$ to one who was under 30 . The median age of mothers at the time of the child's birth was 24 , five years younger than the median age for Australian mothers in 1998, the date for the national statistical release closest to the midpoint of the sample timeframe (Australian Bureau of Statistics, 1998).

\section{Parents' Previous Experiences}

Factors such as experiences of abuse in one's own childhood or having a previous history of abusing another child are known to be associated with abusive and neglectful parenting (Hindley et al., 2006; White et al., 2015). As Table 2.3 shows, a high proportion of the birth mothers were known to have experienced these adversities and the prevalence is likely to be considerably higher, given that this information is often underreported. Almost 1 in 3 mothers were known to have experienced abuse in their own childhoods (42: 31\%) and 20 (15\%) had been in care. Almost half of them (61: 45\%) were known to statutory child welfare services before the birth of the child; in fact, 42 (29\%) had already had at least one child permanently removed. Nine of these mothers had already been permanently separated from three children and three from four, displaying a pattern of repeated pregnancy and removal that is likely to have exacerbated other problems (Broadhurst et al., 2016; Neil, 2013). 
Table 2.3 Past experiences: issues affecting parenting capacity of birth mothers $\left(N=137^{*}\right)$

\begin{tabular}{|l|r|r|}
\hline Issues affecting parenting capacity & Frequency** & Per cent \\
\hline Experience of abuse in own childhood & 42 & 31 \\
\hline In care as a child & 20 & 15 \\
\hline Imprisoned prior to birth of child & 10 & 7 \\
\hline Known to statutory agency prior to birth & 61 & 45 \\
\hline Child(ren) previously removed & 42 & 29 \\
\hline
\end{tabular}

*No information on three birth mothers

${ }^{* *}$ Some birth mothers had more than one of these experiences

Table 2.4 Past experiences: issues affecting parenting capacity of birth fathers $\left(N=120^{*}\right)$

\begin{tabular}{|l|r|r|}
\hline Issues affecting parenting capacity & Frequency** & Per cent \\
\hline Experience of abuse in own childhood & 10 & 8 \\
\hline In care as a child & 8 & 7 \\
\hline Imprisoned prior to birth of child & 26 & 22 \\
\hline Known to statutory agency prior to birth & 35 & 30 \\
\hline Child(ren) previously removed & 25 & 21 \\
\hline
\end{tabular}

*No information on 20 birth fathers

${ }^{*}$ Some birth fathers had more than one of these experiences.

The birth fathers' past experiences are shown in Table 2.4. There is extensive missing data on these variables for the fathers, and it is impossible to tell whether no evidence means a specific factor was not present or there is no record of it being present. As a result, these data are undoubtedly an underestimate. Nevertheless, it is notable that at least 35 $(30 \%)$ were also known to the statutory agency before the birth of the child and at least $25(21 \%)$ had already experienced the removal of a child - for 13 men this had happened more than once. Twenty-six fathers $(22 \%)$ were also known to have served a prison sentence before the birth of the child. We do not have information about the offences, but they are 
likely to be indicators of diminished parental capacity, particularly if they were in response to crimes against the person (White et al., 2015).

\section{Birth Parents' Problems at Time of Adoption Order}

Numerous studies have found that parental mental health problems, drug and alcohol abuse and domestic abuse may reduce parenting capacity and increase the risk that children will be abused or neglected; this is most likely if these problems occur in combination and there are no protective factors such as the presence of a supportive adult in the household (Cleaver et al., 2011; Hindley et al., 2006; White et al., 2015). For instance, depression or the effects of substance and alcohol abuse may mean that parents find it difficult to organise their day-to-day lives and buy food or pay the rent, and children may be neglected. Some mental health problems may cause parents to lose touch with reality and become emotionally unavailable to their children. Parents who are living in an abusive relationship may be unable to protect their children from a violent partner, or from witnessing or becoming affected by the tensions in the household. Parents who misuse alcohol or drugs may spend money needed for essentials on their addiction; they may find it difficult to control their anger and become physically abusive; their children may be unsupervised and exposed to other substance users and unsuitable adults who frequent the home (for further information, see Cleaver et al., 2011).

As Tables 2.5 and 2.6 demonstrate, the birth parents displayed a high prevalence of these problems at the time the adoption order was made. The data indicate that more than half of the birth mothers had problems with substance misuse $(58 \%)$ and/or domestic abuse (51\%) and that more than one in three (37\%) had mental health problems. Moreover, although $49(36 \%)$ birth mothers were struggling with just one of these adversities, 57 (42\%) were dealing with two and $12(9 \%)$ with all three in combination. The 19 birth mothers who showed no evidence of any of these problems were struggling with other issues.

Sixteen of the birth mothers were also known to have cognitive impairments. Parents with cognitive impairment can provide nurturing homes for their children if they have adequate long-term support, but the challenges they already face are exacerbated if mental health problems, 
Table 2.5 Birth mothers: current issues affecting parenting capacity $\left(N=137^{*}\right)$

\begin{tabular}{|l|r|r|}
\hline Issues affecting parenting capacity & Frequency & Per cent $^{* *}$ \\
\hline Mental ill health & 50 & 37 \\
\hline Substance misuse & 79 & 58 \\
\hline Domestic abuse & 70 & 51 \\
\hline None of the above & 19 & 14 \\
\hline
\end{tabular}

*No information on 3 birth mothers

**Percentages add to more than 100 because of comorbidity

Table 2.6 Birth fathers: current issues affecting parenting capacity $\left(N=120^{*}\right)$

\begin{tabular}{|l|r|r|}
\hline Issues affecting parenting capacity & Frequency & Per cent $^{* *}$ \\
\hline Mental ill health & 50 & 37 \\
\hline Substance misuse & 79 & 58 \\
\hline Domestic abuse & 70 & 51 \\
\hline None of the above & 19 & 14 \\
\hline
\end{tabular}

*No information on 3 birth mothers

**Percentages add to more than 100 because of comorbidity

substance misuse and/or domestic abuse are also present (Cleaver \& Nicholson, 2007; Cleaver et al., 2011). Four of these mothers appeared to have cognitive impairment as their major risk factor, but five of them were also struggling with domestic violence and five with combinations of substance misuse, domestic violence and mental ill health.

Table 2.6 shows the prevalence of these risk factors amongst the birth fathers. For the reasons given above, this is undoubtedly an underestimate. Nevertheless, the data do indicate that almost half of the fathers were known to be struggling with substance misuse. In the majority of these cases (44: 80\%), substance misuse was also an issue for the birth mother.

Five of the birth fathers were also known to have cognitive impairments, three of them in combination with both mental ill health and substance misuse. Three of these men also had a partner who had a cognitive impairment.

Although there is evidence that some parents can overcome complex patterns of problems such as these and provide nurturing homes for their 
children (Ward et al., 2019), many are unable to do so within an appropriate timeframe for the child; those who do succeed in making significant changes to lifestyles that threaten their children's wellbeing often need long-term support to sustain hard-won progress (Brown et al., 2016; Ward et al., 2014). The case study of Susan demonstrates the complicated web of problems with which many birth parents struggled, and the issues professionals had to assess in making decisions concerning the children's long-term welfare.

\section{Susan}

Susan was 19 years old when she gave birth to her first child, Michael. At that time Susan was living with Tony, Michael's father.

Personal History

Susan was one of four children and described a happy childhood until she was eight years old when her mother committed suicide. Following this, Susan and her siblings were placed in a strict children's home for four years, where there was frequent physical punishment. In her early teens, Susan left school and returned to her father; however, she ran away shortly afterwards. She soon came to the attention of the police and was assessed at a juvenile centre, where she met Tony when she was 15 years old. By the time of Michael's birth, Susan was using heroin.

Michael

Michael had several visits to hospital during the first couple of months of his life as a result of gastric troubles. He was again taken to hospital when he was three months old with multiple new and old non-accidental fractures to his skull, femurs and tibia. As a result, Michael was placed in foster care and care proceedings commenced.

Michael was made the subject of a care order and moved between various family members and foster care until he was 18 months old. He was then restored to the care of Susan, who had recently separated from Tony. Michael remained in Susan's care for the next two years, occasionally also living with Tony. During this time, Susan continued to use heroin and frequently changed accommodation, often living in housing frequented by numerous adults. When Michael was three years old, the pre-school began to notice a deterioration in his physical presentation and he began to display sexualised behaviour; he was also picked up from pre-school by a succession of different adults to whom he was apparently unrelated. Susan eventually became homeless and was offered emergency accommodation. Finally, after Susan failed to collect him after an arranged stay with Tony, Michael was returned to foster care: 


\section{(continued)}

Why she (birth mother) gave me up, why could she not get her act together? Why bring me into this world, while you're doing all that shit? I feel tainted from birth and I often say to my (adoptive) mum, "I feel like I was doomed in the womb, before I even had a chance."

After Michael returned to foster care, Susan's drug use continued and her criminal activity eventually led to her being imprisoned. At the age of four, Michael was placed with his prospective adoptive parents.

I already had heaps of problems before they adopted me, so it was already embedded into me, because my mum was a drug addict and men coming over and shit happening....

Susan was in prison at the time of the adoption application, and initially contested it; however, she later gave her consent.

\section{Consent to Adoption}

Adoption from out-of-home care is a traumatic experience for most birth parents; feelings of grief and loss are often compounded by anger at an 'unfair, hostile and alienating process' and shame at what may be perceived as a confirmation of their poor parenting capacity (Neil et al., 2010). Susan was one of 52 (37\%) birth mothers who initially withheld their consent to the adoption order. However about one in three birth mothers (49:32\%) gave active consent to the order, including the mothers of $17(8 \%)$ children who entered the programme because their parents had voluntarily relinquished them. Some of these parents placed their children for adoption because they felt that they could not provide them with a nurturing home:

She had her list of what she felt [adoptee] should be getting as a child, how he should be looked after, the whole family situation, the education, all of that, but I always felt that possibly [stepfather] didn't want children, so, it was [adoptee] or [stepfather] and [adoptee] lost out from that point of view... and he said, "Well, my stepfather didn't want children, and I probably really didn't work for her". I wanted him to know that - and she probably did too, that she 
really did care about him, that she's made a decision based on what she thought was the right thing. (Adoptive parent of a young man, aged 8 when permanently placed)

\section{Contested Adoptions}

In New South Wales, an adoption order requires the consent of both the child's birth parents. Under the Adoption Act (New South Wales) 2000, children over the age of 12 must also give consent to their adoption and, if they have been in the care of the proposed adoptive parents for two years, only the child's consent is required. Fifty-eight (28\%) of the Barnardos adoptees met this criterion, and the adoption order was made on the basis of their consent, although the parents of six of them contested it.

The parents of 34 (22\%) children under the age of 12 gave consent to their adoption; a further 94 (62\%) parents did not give consent but did not actively oppose the adoption. Parents of 24 younger children contested the adoption in court; in these cases, both parties were legally represented and had to provide evidence. The courts made adoption orders against parental wishes or without their consent mainly on the grounds that the child was in the care of authorised carers, had established a stable relationship with those carers and that it was in the child's best interest to be adopted by them.

\section{Implications for Open Adoption}

Chapter 1 has described Barnardos' policy on open adoption. The agency is committed to working to ensure that all adoptees have contact with significant members of their birth family; furthermore, the legislation in New South Wales requires a plan for open adoption for all children for whom adoption orders are made. For older children, Barnardos recommends contact with the primary birth parent on average four times a year; for children who come into care when they are very young or have 
a poor attachment to their birth family, the recommendation is for contact between two and four times a year. These policies have been in place throughout the timeframe of the study, although it should be noted that the Supreme Court is the final decision-maker in determining contact levels and does not necessarily follow recommendations from Barnardos or any other agency.

Contact is generally face-to-face (direct); however, there are a (very) few situations where it is restricted to social media or mail contact (indirect). This is in contrast with the experience in Britain, where the majority of contact is indirect, and children in only $5 \%$ of newly established adoptive families have direct contact with birth mothers, $2 \%$ with birth fathers and 15\% with birth siblings (Adoption UK, 2020).

The problems the birth parents were facing give some indication of the challenges involved in implementing a policy of regular direct contact. Parents who were struggling with a violent relationship, substance misuse or mental health problems may well have found it difficult to manage the practicalities of contact - of arriving in the right place at the right time, even if, as was the policy, expenses were paid. There were also emotional hurdles, for contact was painful for birth parents who found that visits reawakened old wounds, or who struggled to accept that their child was becoming attached to another family.

There were so many times [birth mother] was awful to [adoptive mother]. She would say things to her that were really horrible... As you can imagine, being a parent, you feel jealousy and you feel angry because you're incapable of giving your child what you need, but someone else is capable. So she was horrible to her. (Young woman, aged 10 when permanently placed, aged 21 when interviewed)

I know seeing [adoptee] was difficult for [birth mother], and I can imagine why, and it would've been very difficult I'd have imagined for [birth mother] to see [adoptee] drift away and form a relationship with us. I suppose it depends on whether [birth mother] would ultimately admit to herself that she couldn't look after [adoptee], and [adoptee] was in a better place. But I suspect that probably wasn't the case. So I just imagine it would've been torture for [birth mother]. (Adoptive parent of young woman, aged 6 when permanently placed) 
A recent British study found that well over three years after the adoption, $67 \%$ of birth mothers and $56 \%$ of birth fathers were displaying clinical levels of distress (Neil, 2013). Such factors are likely to have resulted in contact arrangements being broken or becoming problematic in other ways, an issue that is explored further in Chap. 6.

I saw him every - once a month or something, there was a visit. But he wouldn't turn up for a lot of them, or he'd turn up with five minutes left of the meeting. (Young woman. aged 8 when permanently placed, aged 31 when interviewed)

If [birth mother] showed up just like - sometimes she'd show up just like you could tell she just wasn't with it that day. And then when she showed up like that, I just was like, oh, well, great. She's doing something again. (Young man, aged 2 when permanently placed, aged 19 when interviewed)

Moreover, there were also reasons why post-adoption contact was impossible, or extremely unlikely, for many of the children in the cohort. As we have already seen, around $10 \%$ of the birth parents had died before the adoption order was made; furthermore, 28 (23\%) birth mothers and 75 (60\%) birth fathers who were known to be alive had already lost contact with their children before the adoption placement. We do not know how strongly the statutory and voluntary agencies which had provided out-of-home care for the children before they were referred to the Barnardos programme promoted contact with birth parents, but research evidence indicates that the longer children remain separated from birth parents, the greater the likelihood that contact will end, particularly if it is not openly encouraged (Millham et al., 1986). More than half of the children (54\%) had already spent over a year separated from their birth families before moving to Find-a-Family and being placed for adoption; ${ }^{1}$ more than one in four had already been separated for two years or more before moving to their adoptive home. In some cases, contact may have been lost because it was not encouraged or facilitated. In others, birth parents may not have wished to have contact; this may have been the case for three children who had been classified as 'abandoned or rejected'

\footnotetext{
${ }^{1}$ The median number of months between entry to care and a Find-a-Family placement was 14 $($ mean $=22.72, \mathrm{sd}=24.984)$; the median number of months between entry to care and entry to the adoptive home was $16($ mean $=26.47, \mathrm{sd}=28.207)$.
} 
before their birth parents lost touch. Finally, loss of contact before adoption may have been as a result of deliberate action by the agencies concerned, since contact may not always have been perceived as being in the child's best interests. Contact between children in out-of-home care and/ or adoptees and birth family members who have seriously abused them in the past can be detrimental to their wellbeing (Neil \& Howe, 2004). As Chap. 3 shows, some of the children in the cohort had had traumatic experiences before separation and these may well have led to contact being curtailed when children entered out-of-home care: for instance, one child, who had been sexually abused by both parents and at least six other adults before separation at the age of five, had no contact with either birth parent by the time of the adoption.

Moreover, where contact had taken place in the period between separation and adoption, it was rarely frequent. Tables 2.7 and 2.8 show the levels of contact between birth parents and at least one of their children at the time of the adoption order.

Table 2.7 Birth mothers: contact at time of adoption order $(N=140)$

\begin{tabular}{|l|r|r|r|}
\hline $\begin{array}{l}\text { Contact with children per } \\
\text { year }\end{array}$ & \multicolumn{1}{|c|}{$\boldsymbol{n}$} & \multicolumn{1}{c|}{ Per cent* } & $\begin{array}{c}\text { Cumulative per } \\
\text { cent }^{*}\end{array}$ \\
\hline 0 & 28 & 23 & 23 \\
\hline 1 & 4 & 3 & 26 \\
\hline 2 & 34 & 28 & 54 \\
\hline 3 & 5 & 4 & 59 \\
\hline 4 & 38 & 31 & 90 \\
\hline 6 & 6 & 5 & 95 \\
\hline 7 & 2 & 2 & 97 \\
\hline 8 & 1 & 1 & 98 \\
\hline Frequency unclear & 1 & 1 & 99 \\
\hline Indirect contact only & 2 & 1 & 100 \\
\hline Total & $\mathbf{1 2 1}$ & $\mathbf{1 0 0}$ & $\mathbf{1 0 0}$ \\
\hline N/A Mother had died & 16 & & \\
\hline Missing & 3 & & \\
\hline
\end{tabular}

*Percentages have been rounded 
Table 2.8 Birth fathers: contact at time of adoption order $(N=140)$

\begin{tabular}{|l|r|r|r|}
\hline $\begin{array}{l}\text { Contact with children per } \\
\text { year }\end{array}$ & \multicolumn{1}{|c|}{ Per cent $^{*}$} & $\begin{array}{c}\text { Cumulative per } \\
\text { cent }^{*}\end{array}$ \\
\hline 0 & 75 & 60 & 60 \\
\hline 1 & 3 & 2 & 62 \\
\hline 2 & 19 & 15 & 77 \\
\hline 3 & 2 & 2 & 79 \\
\hline 4 & 20 & 16 & 94 \\
\hline 5 & 1 & 1 & 95 \\
\hline 6 & 3 & 2 & 97 \\
\hline Frequency unclear & 1 & 1 & 98 \\
\hline Indirect contact only & 2 & 2 & 100 \\
\hline Total & 126 & 100 & 100 \\
\hline N/A Father had died & 11 & & \\
\hline Missing & 3 & & \\
\hline
\end{tabular}

${ }^{*}$ Percentages have been rounded

Although contact was mainly direct, as already indicated, almost a quarter of the birth mothers and over half the birth fathers no longer had contact with their children by this time. Additionally, only $52(42 \%)$ birth mothers and $26(21 \%)$ birth fathers saw their children more than twice a year; only $9(8 \%)$ birth mothers and $4(3 \%)$ birth fathers saw their children more than once every three months and no birth parents had contact at more than six weekly intervals. This low level of contact indicates that, for most parents, the arrangements may have seemed more about keeping in touch than maintaining a relationship. The experiences of Susan and her son, Michael, whose history has been presented earlier in this chapter, demonstrate the complexities of making and fulfilling contact arrangements when parents are struggling with interlocking problems, they have inadequate access to professional support and their children are permanently placed away from home. 


\section{Susan}

\section{Susan's Contact with Michael}

Before the Adoption

Following Michael's re-entry to care when he was three, Susan had very sporadic and limited contact with him; social workers also found it difficult to locate or make contact with her.

After the Adoption

Throughout Michael's childhood, Susan was frequently imprisoned. During these times, she would make contact with Barnardos and contact between Susan and Michael was gradually re-established. However, Susan was not able to sustain this following her release from prison:

We had a couple of visits while she was still inside. And then she was coming out, and then she had promised on her life that she would keep contact with (adoptee), and didn't even turn up for the first visit, which was a bit shattering for (adoptee), and made me very angry. (Adoptive mother)

So, she just didn't want me, didn't want to see me, the drugs - Like she never really wanted me in the first place... (Michael)

Susan lost contact with Michael until he was in his late teenage years, when he searched for her and succeeded in re-establishing it. He went to stay with her for a period but this was not a positive experience for either and contact again ceased. Michael had had no contact with Susan for several years prior to her death from a chronic medical condition when he was in his 20 s.

The purpose of contact is an issue that needs to be explored within the context of open adoption, as well as in other situations in which children are separated from birth parents (Iyer et al., 2020). The high proportion of birth parents who had no or minimal contact with their children before the adoption order is also a factor to be taken into account in assessing the success of Barnardos' attempts to implement open adoption.

Recent research demonstrates that open communication about adoption issues, both within and between the parties in the adoption triangle (adoptees, adoptive parents and birth parents) is of greater significance to the adjustment and long-term wellbeing of adopted children than contact per se (Brodzinsky, 2006; Kohler et al., 2002). Although contact obviously makes communication easier, it is not a sine qua non for successful adjustment. Some families have contact, but no communication 
about adoption-related issues and their children may find it harder to adjust to their situation than those who have no contact with birth families, but whose adoptive parents provide them with encouragement and opportunities to ask questions and discuss these subjects (Brodzinsky, 2006). Chapters in Part II of this book explore these issues further.

\section{Changes over Time}

The children entered their adoptive placements over a period lasting slightly more than 30 years (February 1979-July 2011), and during that time there were changes to admission criteria as the age range expanded to include more younger children (see Chap. 1 for further details). It seems likely that the birth parents also changed over this period. We have sorted the data collected at the time children were placed for adoption into time periods, mirroring the changes in policy: 1 February 1979-31 August 1985 (young children in long-term foster care); 1 September 1985-30 June 1991 (older primary-school-aged children with behavioural/emotional challenges); 1 July 1991-30 June 2007 (wider age range) and 1 July 2007-30 June 2013 (inclusion of infants).

Birth mothers' age at the time of the child's birth tended to increase as time passed. In the first time period, they were significantly younger (mean $=22.5$ years old) than those in the two time periods covering July 1991 up to June 2013 ( 25 years and 26 years respectively). ${ }^{2}$ Contact with birth parents also changed significantly between the different time periods. Those adopted between 1 July 1991 and 30 June 2007 (when the age range was increased to include younger children) had significantly more contact with birth parents at the time of the adoption order application than those adopted between 1 January 1979 and 31 August 1985 (children adopted by long-term foster carers). ${ }^{3}$

\footnotetext{
${ }^{2} t(21.2)=-2.13 ; p=0.45$, and $t(42.5)=-2.19 ; p=0.034$.

${ }^{3} \chi^{2}=8.54 ; d f=3 ; p=0.036$.
} 


\section{Conclusion}

The following chapter explores the children's experiences, both while living with their birth parents before separation and during the period between entering out-of-home care and reaching their final placement with adoptive parents. Significant levels of abuse and neglect experienced by the children while living with their birth parents were the major reasons for decisions to place them away from home. Maltreatment was commonly related to parental factors such as mental ill health, substance misuse and domestic violence, which carry a risk of adversely impacting on parenting capacity and parent/child relationships, especially if there are no protective factors present. These factors often occurred in combination, increasing the likelihood of maltreatment: the data presented in this chapter show that over half the birth mothers (69: 51\%) were struggling with two or more of these factors at the time the adoption order was made.

Such adversities also had an impact on the extent to which contact between birth parents and children was feasible (and, in a few cases, advisable) after separation. Personal issues such as a parent's ability to arrive at the correct meeting place at the assigned time and emotional issues surrounding parents' disengagement from the family unit or the circumstances of the separation would have acted as obstacles to contact. The length of time that children had spent in out-of-home care and the frequency of contact during that period, together with the extent to which agencies promoted (or sometimes obstructed) a contact plan, would all have had an impact on the likelihood of birth parents and children keeping in touch, let alone maintaining some sort of relationship before the child was admitted to the Barnardos programme. The interviews with adult adoptees reveal that most parents did not succeed in extricating themselves from the complex web of adversities that had led to the removal of their child (see also Ward et al., 2019). The few who did manage to overcome their problems moved on to new partners with whom they had other children; they only rarely developed a stronger relationship with the child who had been adopted.

In assessing the effectiveness of the policy of open adoption, these antecedents need to be taken into account. At the heart of this policy is 
the expectation that contact with parents will continue after the adoption order has been made: the outcomes of this policy need to be understood within a context in which $60 \%$ of birth fathers and $23 \%$ of birth mothers had already lost contact with their children before this had happened.

\section{Key Points}

- There were 142 birth families, with $58 \%$ of the children entering Finda-Family with at least one sibling. Almost all the children (205: 98\%) had been primarily looked after by their birth mothers. There was comprehensive information on 140 birth mothers and on 120 (85\%) of the birth fathers. Seventeen (12\%) fathers were unknown.

- The majority of the birth mothers were Australian or New Zealanders (111: 79\%) or European (21: 16\%). Three birth fathers, but none of the birth mothers, were Aboriginal.

- When the children were born, most birth mothers (98:70\%) were still in a relationship with the birth father; only $14(10 \%)$ were still in this relationship by the time the children were adopted.

- One in three (42:31\%) birth mothers are known to have experienced abuse in their own childhoods and $20(15 \%)$ had been in care. Almost half of them (61: 45\%) were known to statutory child welfare services before the birth of the child. Forty-two (29\%) birth mothers had already experienced the permanent removal of at least one child; nine had already been permanently separated from three children and three from four.

- At least 35 (30\%) birth fathers were also known to the statutory agency before the birth of the child and at least 25 (21\%) had already experienced the removal of a child, 13 of them more than once. Extensive missing data on birth fathers suggests that these are under-estimates.

- At the time of the adoption order more than half the birth mothers had chronic problems including substance misuse $(58 \%)$, domestic abuse (51\%) and/or mental health problems (37\%). Forty-nine (36\%) were struggling with just one of these adversities; 57 (42\%) were dealing with two and $12(9 \%)$ with all three in combination. Only 19 birth mothers showed no evidence of any of these problems. 
- At least 54 (45\%) birth fathers were misusing substances; 28 (23\%) were in abusive partnerships; and $12(10 \%)$ had mental health problems. Missing data mean that this is undoubtedly an underestimate.

- In at least $44(31 \%)$ birth families, both parents were misusing substances.

- Sixteen birth mothers and five birth fathers were also known to have cognitive impairments. Twelve of these birth mothers and three of these birth fathers were also struggling with mental ill health, domestic abuse and/or substance misuse. In three families, both birth parents had cognitive impairments.

- At the time of the adoption order, almost a quarter of the birth mothers $(23 \%)$ and over half the birth fathers $(60 \%)$ no longer had contact with their children. Only 52 (42\%) birth mothers and 26 (21\%) birth fathers saw their children more than twice a year; only $9(8 \%)$ birth mothers and $4(3 \%)$ birth fathers saw them more than once every three months. This is the context within which outcomes of open adoption policies should be evaluated.

\section{References}

Adoption UK. (2020). Adoption barometer: A stocktake of adoption in the UK. Adoption UK. https://www.adoptionuk.org/Handlers/Download.ashx? IDMF=c79a0e7d-1899-4b0f-ab96-783b4f678c9a. Accessed 2 Oct 2020.

Australian Bureau of Statistics. (1998). Births Australia 1998. https://www.ausstats.abs.gov.au/ausstats/subscriber.nsf/0/CA25687100069892 CA256889000C79F4/\$File/33010_1998.pdf. Accessed 10 Oct 2020.

Broadhurst, K. E., Alrough, B., Mason, C. S., Yeend, E., Kershaw, S., Shaw, M., \& Harwin, J. (2016). Women and infants in care proceedings in England: New insights from research on recurrent care proceedings. Family Law, 46(2), 208-211.

Brodzinsky, D. (2006). Family structural openness and communication openness as predictors in the adjustment of adopted children. Adoption Quarterly, 9(4), 1-18.

Brown, R., \& Ward, H. (2014). Cumulative jeopardy: How professional responses to evidence of abuse and neglect further Jeopardise children's life chances by being out of kilter with timeframes for early childhood development. Children and Youth Services Review, 47(3), 260-267. 
Brown, R., Ward, H., Blackmore, J., Thomas, C., \& Hyde-Dryden, G. (2016). Eight-year-olds identified in infancy as at risk of harm: Report of a prospective longitudinal study. RR543. Department for Education. https://assets.publishing.service.gov.uk/government/uploads/system/uploads/attachment_data/ file/534376/Eight-year-olds_identified_in_infancy_as_at_risk_of_harm.pdf. Accessed 20 Oct 2020.

Bywaters, P. (2013). Inequalities in child welfare: Towards a new policy, research and action agenda. British Journal of Social Work, 45(1), 1-18.

Bywaters, P., Bunting, L., Davidson, G., Hanratty, J., Mason, W., McCartan, C., \& Steils, N. (2016). The relationship between poverty, child abuse and neglect: An evidence review. Joseph Rowntree Foundation.

Cleaver, H., \& Nicholson, D. (2007). Parental learning disability and children's needs: Family experiences and effective practice. Jessica Kingsley Publishers.

Cleaver, H., Unell, I., \& Aldgate, J. (2011). Children's needs - Parenting capacity: Child abuse: Parental mental illness, learning disability, substance misuse and domestic violence (2nd ed.). The Stationery Office.

Hindley, N., Ramchandani, P. G., \& Jones, D. P. H. (2006). Risk factors for recurrence of maltreatment: A systematic review. Archives of Disease in Childhood, 91(9), 744-752.

Iyer, P., Boddy, J., Hammelsbeck, R., \& Lynch-Huggins, S. (2020). Contact following placement in care, adoption, or special guardianship: Implications for children and young people's well-being. Evidence review. Nuffield Family Justice Observatory.

Kohler, J. K., Grotevant, H. D., \& McRoy, R. G. (2002). Adopted adolescents' preoccupation with adoption: The impact on adoptive family relationships. Journal of Marriage and Family, 64, 93-104. https://doi. org/10.1111/j.1741-3737.2002.00093.x. Accessed 19 Oct 2020.

Millham, S., Bullock, R., Hosie, K., \& Haak, M. (1986). Lost in care: The problems of maintaining links between children in care and their families. Gower.

Neil, E. (2013). The mental distress of the birth relatives of adopted children: 'Disease' or 'unease'? Findings from a UK study. Health and Social Care in the Community, 21(2), 191-199.

Neil, E., Cossar, J., Lorgelly, P., \& Young, J. (2010). Helping birth families: Services, costs and outcomes. BAAF.

Neil, E., \& Howe, D. (2004). Contact in adoption and permanent foster care. BAAF.

Wade, J., Biehal, N., Farrelly, N., \& Sinclair, I. (2011). Caring for abused and neglected children: Making the right decisions for reunification or long-term care. Jessica Kingsley Publishers. 
Ward, H., Brown, R., Blackmore, J., Hyde-Dryden, G., \& Thomas, C. (2019). Identifying parents who show capacity to make and sustain positive changes when infants are at risk of significant harm. Developing Practice, The Child, Youth and Family Work Journal, 54, 47-61.

Ward, H., Brown, R., \& Hyde-Dryden, G. (2014). Assessing parental capacity to change when children are on the edge of care: An overview of current research evidence. RR369. Centre for Child and Family Research, Loughborough University and Department for Education. https://assets.publishing.service. gov.uk/government/uploads/system/uploads/attachment_data/file/330332/ RR369_Assessing_parental_capacity_to_change_Final.pdf. Accessed 30 Dec 2020.

Ward, H., Munro, E. R., \& Dearden, C. (2006). Babies and young children in care: Life pathways, decision-making and practice. Jessica Kingsley Publishers.

White, O. G., Hindley, N., \& Jones, D. P. H. (2015). Risk factors for child maltreatment recurrence: An updated systematic review. Medicine, Science and the Law, 55(4), 259-277.

Open Access This chapter is licensed under the terms of the Creative Commons Attribution 4.0 International License (http://creativecommons.org/licenses/ by/4.0/), which permits use, sharing, adaptation, distribution and reproduction in any medium or format, as long as you give appropriate credit to the original author(s) and the source, provide a link to the Creative Commons licence and indicate if changes were made.

The images or other third party material in this chapter are included in the chapter's Creative Commons licence, unless indicated otherwise in a credit line to the material. If material is not included in the chapter's Creative Commons licence and your intended use is not permitted by statutory regulation or exceeds the permitted use, you will need to obtain permission directly from the copyright holder. 